\title{
CHALLENGING TIMES FOR POWER PLANTS
}

\author{
by \\ Miodrag M. Mesarović \\ Energoprojekt Entel, Belgrade, Serbia \\ Review paper \\ DOI: $10.5937 /$ termoteh
}

\begin{abstract}
Power plants face today, and will continue so in the future, a variety of challenges, along with many uncertainties as well. Overshadowed by an inevitable and burdensome transition to a low carbon economy as the most exploited subject, there are also numerous issues, often overseen or even neglected, that may make position of power plants critical with respect to the security of supply, particularly when considering a massive move of mobility towards electric drives or a high penetration of intermittent renewables, for example. Exposed to a brutal and often unfair competition with subsidized players on the open market, some power plants are being economically and/or politically disqualified by ones based on another kind of primary energy sources. Addressed briefly are the above and some other issues, including water-energy nexus, energy storage, clean coal and CCS technologies, decentralized generation, role of virtual power plants, smart networking, cyber threats, as well as energy price volatility, global recession, geopolitical concerns, cross-border cooperation, climate deal, strong or smart solutions for security of energy supply, and some other dilemmas, challenges and/or uncertainties attributed to power plants in the times to come.
\end{abstract}

Key words: Power plants, challenges, uncertainties, security of supply, mobility, climate deal.

\section{INTRODUCTION}

Each stage of economic development has been accompanied by a characteristic energy transition from one major fuel source to another. Historically, as supplies of firewood and other biomass energy proved insufficient to support growing economies, people turned to hydropower, then to coal during the $19^{\text {th }}$ century, and then to oil and natural gas during the $20^{\text {th }}$ century. Today's energy system is undergoing an unprecedented transition, which is the most challenging for power plants due to a change in energy sources away from fossil fuels towards renewable energy sources (RES). This transition is motivated by a combination of many factors, including concerns about environmental impacts (particularly climate change), limits on fossil fuel supplies, prices, and technological change. One key trend that emerges is the significant decline in the cost of renewable generation as a result of the use of improved technologies and continued governmental support in recent years.

The energy transition has the potential to change the way in which the energy is produced and to impact operating models and the economic foundation of power systems. Open energy markets are further increasing in complexity, accelerated by a fast moving technological innovation, and shifting consumer expectations. Particularly high growth in the renewable energies market, as well as the new capacities and high growth rates in developing countries have changed the landscape for the energy sector. This has contributed to falling prices and increased decoupling of economic growth and emissions. There is also a significant need to balance between environmental impacts, social equity considerations and increased needs for resilience and security of power supply.

Greater self-sufficiency and diversity of supply, necessary to counteract the risks associated with the dependence on imports from other countries which leaves the energy system vulnerable to changes that are beyond the control at national level, resulted in a more diversified energy mix as the nations are increasingly 
concerned with the issue of energy security. Resilience to external shocks can be improved through diversity of supply, a balance between local production and imported energy, and participation in regional networks.

The aim of this paper is to investigate major challenges faced by the energy sector with focus on the power plants and to highlight the key trends and the implications for the energy policy, which are crucial to understand the new realities for the energy sector as a whole and for the power plants in particular. Addressed are challenges for power plants posed by the current focus on sources of primary energy, both renewable and conventional, as well as on the fast developing technologies that have an impact on competitiveness and operation of the power plants. Environmental and climate change issues are also addressed, followed by a review of the economic challenges as the major driver of the current transition in the power sector.

\section{CHALLENGIES RELATED TO SOURCES OF PRIMARY ENERGY}

\section{Renewable energy sources}

Renewable energy sources are unlimited, as supplies are continually replenished through natural processes. Every world region has some renewable energy resources, though availability and cost of using these vary. Most renewable energy is ultimately solar energy. Also, biomass, wind, and hydropower are just secondary sources of solar energy. Hydro power comes from falling water, which occurs because solar energy evaporates water at low elevations that later rains on high elevations. The Sun creates wind through differential heating of the Earth's surface. Biomass energy comes from plant produced in the photosynthesis process, which is driven by the Sun. Nonsolar renewable energy sources include geothermal energy, which comes from the Earth's core, in some combination of energy left from the origin and decay of nuclear materials there.

Global consumption of renewable energy sources has increased greatly during the last decade, Table 1, [1].

Table 1: Global Share of Primary Energy Sources

\begin{tabular}{|c|c|c|c|}
\hline Primary Energy & 2005 & 2010 & 2015 \\
\hline Renewables & $6.82 \%$ & $7.83 \%$ & $9.57 \%$ \\
\hline Hydro & $6.05 \%$ & $6.44 \%$ & $6.79 \%$ \\
\hline Wind & $0.22 \%$ & $0.63 \%$ & $1.44 \%$ \\
\hline Solar & $0.01 \%$ & $0.06 \%$ & $0.45 \%$ \\
\hline Other & $0.54 \%$ & $0.70 \%$ & $0.89 \%$ \\
\hline Fossil Fuels & $87.45 \%$ & $87.03 \%$ & $85.99 \%$ \\
\hline Oil & $35.96 \%$ & $33.49 \%$ & $32.94 \%$ \\
\hline Gas & $22.88 \%$ & $23.70 \%$ & $23.85 \%$ \\
\hline Coal & $28.61 \%$ & $29.84 \%$ & $29.20 \%$ \\
\hline Nuclear & $5.73 \%$ & $5.14 \%$ & $4.44 \%$ \\
\hline Total & $100.0 \%$ & $100.0 \%$ & $100.0 \%$ \\
\hline
\end{tabular}

Table 2, [2] World Energy Council (WEC) predicts that by 2060 percentage of electricity in total final energy production could reach penetration levels as high as $30 \%$, with up to $98 \%$ coming from non- $\mathrm{CO}_{2}$ emitting technologies, a 3-fold increase over the current share with $40 \%$ coming from solar and wind technologies alone, representing a 10 -fold increase over current share, [3]. Faced with the fast change on all fronts, utilities are working to deploy the new power generation and energy storage technologies and to integrate real-time forecasting, and an advanced visualization to better manage a growing penetration of the distributed intermittent as well as weather dependent renewable energy sources. hours of operation per year of solar PV and wind, pose challenges to their large-scale development. The RES regulation and policies present differences in particular countries, but RES enjoy priority of dispatch in most of them. The use of various support and incentive schemes had a strong impact on the world RES development. Financial incentives have been widely used for promotion of RES. The most popular form is 'feed-in tariffs' that are in use in many countries and are fixed for specified time periods. Solar and wind power continue their rapid growth in Europe and worldwide,

Table 2: RES capacity development in the last five years

\begin{tabular}{|c|l|c|c|c|c|c|}
\hline RES & Region & 2011 & 2012 & 2013 & 2014 & 2015 \\
\hline \multirow{3}{*}{ Solar PV } & World, GW & 69 & 100 & 139 & 181 & 222 \\
\cline { 2 - 7 } & Europe, GW & 52 & 70 & 81 & 88 & 96 \\
\cline { 2 - 7 } & Europe, \% & $75 \%$ & $70 \%$ & $58 \%$ & $49 \%$ & $43 \%$ \\
\hline \multirow{3}{*}{ Wind } & World, GW & 239 & 283 & 318 & 370 & 432 \\
\cline { 2 - 7 } & Europe, GW & 95 & 108 & 119 & 131 & 144 \\
\cline { 2 - 7 } & Europe, \% & $40 \%$ & $38 \%$ & $37 \%$ & $35 \%$ & $33 \%$ \\
\hline \multirow{3}{*}{ Total } & World, GW & 308 & 383 & 457 & 551 & 654 \\
\cline { 2 - 7 } & Europe, GW & 147 & 178 & 200 & 219 & 240 \\
\cline { 2 - 7 } & Europe, \% & $48 \%$ & $46 \%$ & $44 \%$ & $40 \%$ & $37 \%$ \\
\hline
\end{tabular}
Variability and average low equivalent 


\section{Hydro Power}

Hydropower is the leading renewable source for electricity generation globally, supplying $71 \%$ of all renewable electricity at the end of 2015, while still undeveloped potentials amount approximately to $10,000 \mathrm{TWh} / \mathrm{year}$ worldwide, [1]. Hydroelectric power could be regarded as intermittent due to its unpredictable nature. It is partially true for run-off-the river hydro, even if large rivers allow long duration anticipation and precise prediction. The hydro with reservoirs is storable energy which gives flexibility and stability to the electricity grid. The volume of water available in the reservoirs can be anticipated about a year in advance so that the capacity may be guaranteed.

An estimated 62,500 power plants are operating around the world, with a total installed generating capacity of more than $6,000 \mathrm{GW}$ in 2015, [4]. The nine largest operating power plants in the world by capacity are all hydro electric power plants. The global hydropower capacity increased by more than $30 \%$ between 2007 and 2015 accounting to a total of $1209 \mathrm{GW}$ in 2015, of which $145 \mathrm{GW}$ is pumped storage. Four of the world's ten largest power plants are located in China, and all four of those plants began operating in the past 13 years, Figure 1, [4].
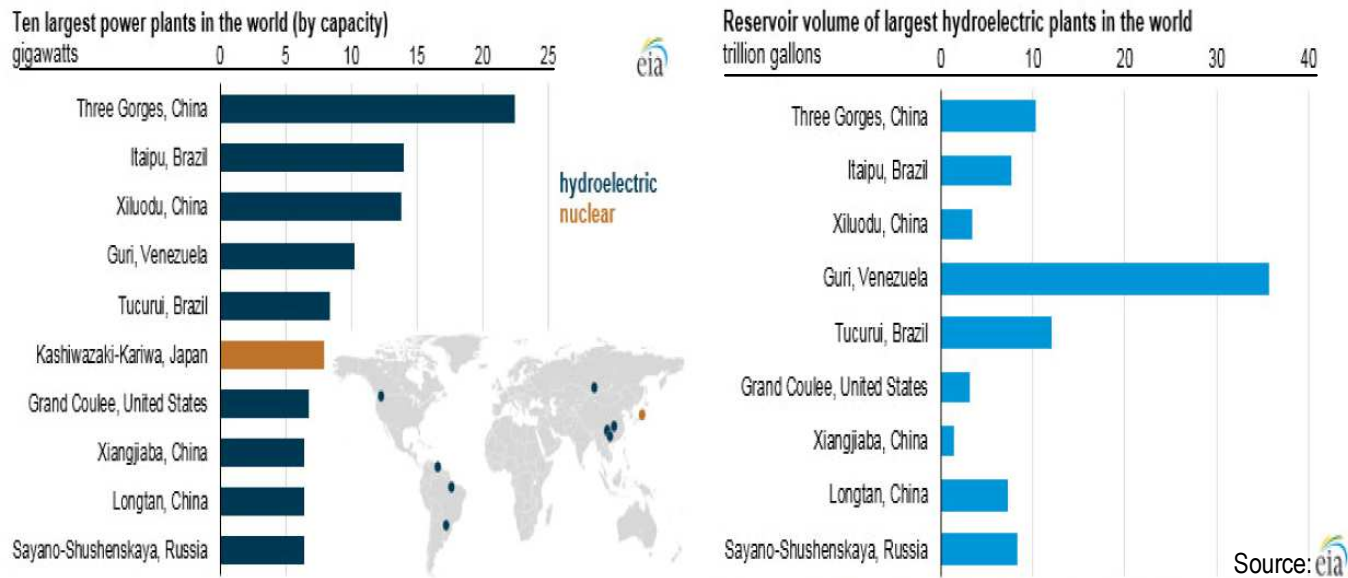

Figure 1: World's largest hydropower plants by capacity (left) and by reservoir volume (right)

Several countries are building large power plants to meet growing electricity demand. Some of the soon-tobe-largest power plants in the world are hydroelectric plants under construction in countries such as China and Brazil. The world's largest dam, Three Gorges in China, has a capacity of $22.5 \mathrm{GW}$. Hydroelectric power is the second-largest source of electricity in China, after coal, and accounted for $20 \%$ of the country's total generation in 2015. South America is home to three of the world's largest power plants. Brazil's Itaipu dam is the second-largest power plant in terms of capacity (14 GW), but ranked first in the world in generation, producing 89.5 TWh in 2015, compared to Three Gorges output of 87 TWh, [4]. Differences in seasonal flows of the Yangtze and Parana rivers account for differences in the output of the Three Gorges and Itaipu dams, respectively. The Kashiwazaki-Kariwa nuclear power plant in Japan is the largest nuclear plant in the world and the sixth-largest power plant of any type in the world. The Sayano-Shushenskaya dam in Russia is the tenth-largest power plant in the world, but it is the largest power plant in Russia, with a capacity of $6.4 \mathrm{GW}$, [4].

Hydropower can be generated when needed to meet rapid or unexpected fluctuations in demand due to the storage reservoir of water, [5]. There are, however, limited possibilities for new sites and environmental impacts through land use and conversion. Hydroelectric dams and micro hydropower plants are competitive in the energy market, but environmental concerns have slowed their adoption. Harmonization and modification of market rules and subsidy systems is important to fully exploit the balancing capability of hydropower, and its support for stabilization of the grid. Integration of electricity markets generally improves the business case for interconnections but different market rules such as having a capacity market connected to energy only markets create suboptimal business cases. When increasing the renewable electricity production in Europe, interconnections between countries will be more important. Large wind power capacities in countries like Germany and Denmark need to be balanced with storage capacities in hydro power in countries like Norway, or mountain regions as Alps, for example. 
Mesarovic, M.: Challenging Times for Power Plants

TERMOTEHNIKA, vol. 43, no. 1-4, 2017, pp. 1-22

\section{Solar Power Plants}

Solar power systems are the fastest growing renewable energy source worldwide. There are two major types of solar power plants: concentrated solar power plants (CSP), and photovoltaic (PV) solar installation, Figure 2.

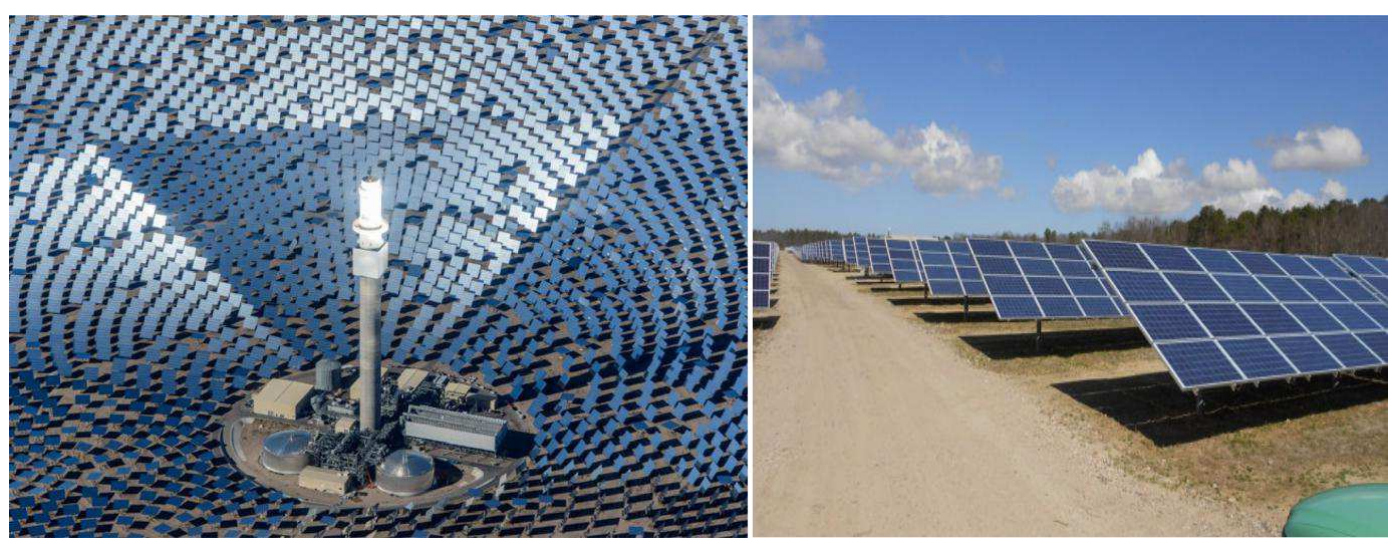

Figure 2: Solar power plants (left: Concentrating Solar CSP; right: Photovoltaic PV)

Global installed capacity for solar-powered electricity has seen an exponential growth, reaching around 227 GW at the end of 2015, producing $1 \%$ of all electricity used globally. The total capacity for solar heating and cooling in operation in 2015 is estimated at $435 \mathrm{GW}$ thermal, [1]. Roughly $70 \mathrm{GW}$ of solar capacity will be built in the US by 2020 , most of it from distributed resources such as residential and rooftop solar PVs. As a point of reference, Germany currently has roughly $35 \mathrm{GW}$ of solar capacity, [6].

The solar PV module prices have declined around 80\% since 2007 (from \$4/W in 2007 to \$1.8/W in 2015), [7]. Much of the cost reduction has come from declining module costs, inverter and so-called soft cost. While the big solar had a steady decline in average cost from 2014 to 2015 ending at a level of $\$ 1.33 / \mathrm{W}$, the rooftop solar costs have remained around $\$ 3.50 / \mathrm{W}$ over the same period, [7]. Although the rooftop solar has enjoyed a decline in module cost, an increase in soft costs is offsetting much of this decline. In 2015, soft costs have actually risen by $7 \%$, primarily due to rising customer acquisition costs, which means that rooftop solar companies are spending more to convince people to put solar on their roofs.

Looking to the future, big solar companies are focused on reducing costs to prepare for the expected demise of the incentives and along the way creating more demand for their generation, which may mean that the incentives become irrelevant to their future plans, expecting that they would install solar on trackers for less than \$1 per watt by 2017, which may be the case, [7]. On the other hand, given the cost structure of rooftop solar and the ferocious battles that rooftop companies wage when threatened by the elimination of net metering incentives, it would appear that incentives are not only relevant but critical to the ongoing progress of the rooftop industry. So, it would seem that, without incentives, the scales would clearly tip in favor of big solar. It would additionally seem that, big carbon-reduction goals, the big solar is needed to keep the price of electricity reasonable.

\section{Wind Power Plants}

The wind power plants are present today in more than 80 countries worldwide, of which 28 countries have more than 1,000 MW installed, including 17 countries in Europe, 4 in Asia-Pacific (China, India, Japan \& Australia), 3 in North America (Canada, Mexico, US), 3 in Latin America (Brazil, Chile and Uruguay), and 1 in Africa (South Africa). At the end of 2015, 8 countries had more than $10 \mathrm{GW}$ installed, including China (145,362 MW), the US (74,471 MW), Germany (44,947 MW), India (25,088 MW), Spain (23,025 MW), UK (13,603 MW), Canada (11,205 MW), and France (10,358 MW), [8]. In 2016 Brazil joined the '10 GW club', [1].

At the end of 2015 global wind power generation capacity reached 435 GW (420 GW onshore, 15 GW offshore), which is $7 \%$ of total world power generation capacity, [1]. To push this figure higher, governments are implementing a range of measures and support schemes like feed in tariffs. As shares of wind continue to increase, countries take steps to create power systems that can integrate large amounts of variable wind energy, exploring smart grids, storage technologies and other grid management mechanisms. 
However, challenges still remain for wind farms development on many regional markets. In Europe a cocktail of policy changes, economic crises and austerity measures is viewed as likely to produce difficulties, although a shift away from fossil fuel-fired power could provide a boost. The worldwide wind capacity could reach 2,110 GW by 2030 , and even $5,800 \mathrm{GW}$ by 2050 , [8]. Continuing growth is predicted for North America, where the US is experiencing a 'wind rush' due to unwonted policy stability. With new markets developing rapidly across Africa, Asia and Latin America, and policy stability in the US market, as well as strong and continued commitment from India and China, the prices for wind power, both on- and off-shore, are dropping rapidly.

As the offshore wind farms are becoming more financially, aesthetically and environmentally viable, they are turning to floating supports to enable wind turbines to move into deeper waters farther from the coast, Figure 3.

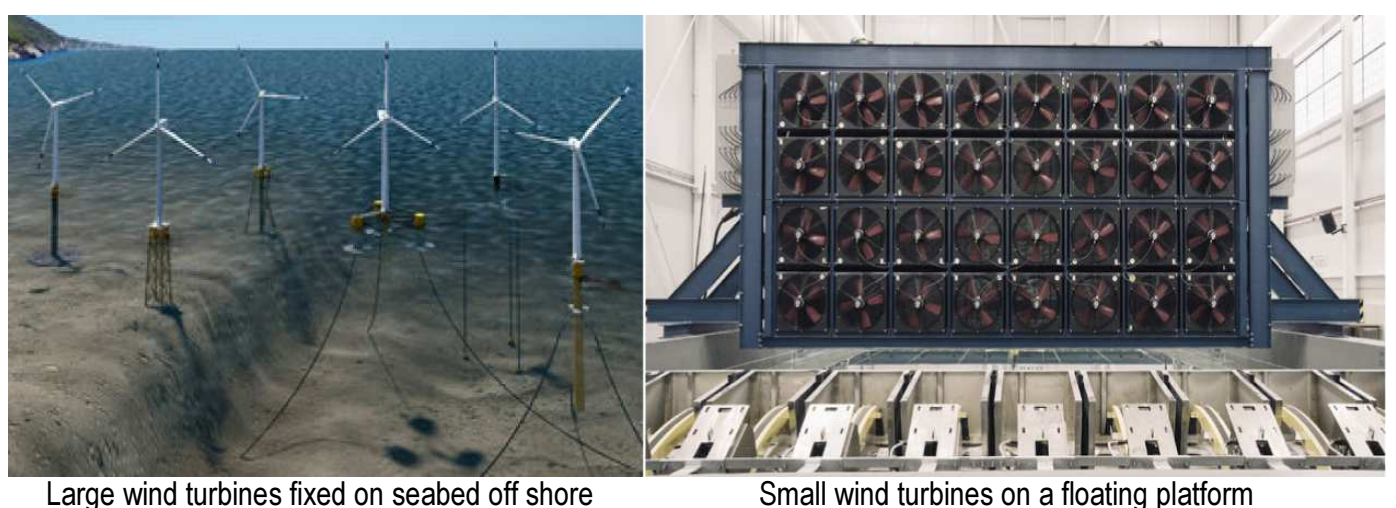

Large wind turbines fixed on seabed off shore

Small wind turbines on a floating platform

Figure 3: Off shore wind power generation plants

The use of floating power plants could help to overcome some obstacles that have deterred offshore wind farms. Right now, almost all offshore wind turbines require fixed platforms built into the seafloor, but floating turbines, with anchors, would mean new flexibility in where wind farms could be placed, with potentially less impact on marine life and less opposition from the human neighbors on shore, [9].

Conventional offshore wind developments, with foundations deep beneath the ocean floor, are increasingly common in Europe. But, partly because of public opposition, fixed offshore turbines are just starting in the US, with more than half of the offshore wind potential in deeper waters in parallel with floating technologies adapted from deepwater oil and gas drilling rigs, which use tethers and anchors to moor platforms to the seabed. The wind farms can be located farther out at sea, where they would not be visible from land, and their anchoring mechanisms have a smaller, more flexible footprint than the embedded foundations of conventional wind turbines. Floating platforms could open deeper waters to wind energy development. The floating platforms could result in less environmental disturbance and easier transportation and installation, so that floating power plants may come to outnumber fixedfoundation installations. However, cost is an obstacle that must be overcome, because the floating farms are more expensive to build than land-based ones, and probably would cost even more than fixed offshore installations, [9].

\section{Geothermal Power Plants}

Geothermal power generation is concentrated in a small number of countries which have the geothermal energy resources. There are two types of geothermal systems: hydrothermal systems and enhanced geothermal systems. A naturally occurring hydrothermal system consists of a hot spring, while an enhanced geothermal system (EGS) is a man-made reservoir in areas of hot rocks by transferring heat from the fractured hot rocks, and transporting the energy to the surface to generate electricity. The geothermal potential makes it possible to extract energy by drilling wells into reservoirs down to several kilometers depth, and from the high-temperature water, heated by the Earth's magma there, superheated steam can be brought to the surface at $400-500^{\circ} \mathrm{C}$ and used in steam turbines for efficient electricity production, [10].

The process may involve injecting water and chemical mixtures at high pressures into the ground, and breaking open cracks in the rock below the surface. A number of subsurface technologies utilized by oil and gas industries can be utilized by geothermal industry for EGS, so that technological advances in either sector accrue benefits to both, as subsurface challenges and needs facing both the oil and gas and EGS industries are similar. An innovative technology may be used to produce electricity needed by an oil and gas field, when geothermal power can be 
generated from hot water that flows from wells and thus offset the need for costly transmission construction and reduces energy costs at remote oil fields.

The high temperature drilling tools with operating parameters that allow those tools to be deployed in extremely hot subsurface conditions, can be utilized by the oil and gas industry as they expand to deeper and hotter commodity extraction, as well as the EGS industry as they develop hot geothermal reservoirs. Similarly, stimulation and drilling technologies are used by both industries, so advancements in this area benefit both sectors. Once demonstrated, these advancements may enable the recovery of resources from the produced fluids from oil and gas. A research program is also conducting an evaluation of elevated temperature fluids to assess the potential for these dissolved minerals within geo-fluids and oil and gas fluids to establish a resource estimate, [11].

\section{Bio-energy}

Many of the coal fired boilers can be fired with a part or fully with biomass. It is easy to burn wooden biomass in a coal fired boiler if it is milled down to typical sawdust size. Moisture content does not matter much. The use of solid and gaseous biomass for electricity generation can provide multiple environmental and socio-economic opportunities and benefits. Biomass, unlike most other RES, can be stored relatively easily and can provide energy to dispatch as needed, [12]. On the other side, the production, extraction, processing, transport and conversion of biomass into final energy can sometimes have adverse impacts for biodiversity, natural habitats and ecosystem services, and soil and water quality.

The challenge in developing renewable energy sources not only needs to focus on making the relevant technologies more attractive and cost-efficient, but also to ensure that their entire life-cycle remains sustainable. In this context, the co-firing of biomass might be a low cost and efficient way to reduce emissions of greenhouse gases (GHGs) from electric power production, but should be viewed critical from resource efficiency and energy efficiency perspectives, particularly if this implies long distance transports of biomass and inefficient conversion processes with no or limited use of surplus heat. Yet at the same time, efficient utilization of surplus heat in small to medium scale dedicated biomass power plants and cogeneration processes can contribute to the decarbonisation of both, heat and electricity generation, sectors, [12].

Biomass power generation has increased steadily by upgrading older coal plants to biomass plants. Biomass energy is used in conjunction with cogeneration or district heating to increase energy efficiency. However a consistent source of biomass fuel continues to be a major problem to overcome. Bio-energy is the largest renewable energy source with $14 \%$ of $18 \%$ renewables in the energy mix, and provides $10 \%$ of global energy supply, [1].

Biogas for electricity generation is rising rapidly in Europe. By the end of 2012, more than 13,800 biogas power plants, with a total installed capacity of $7.5 \mathrm{GW}$, were in operation. The share of total EU electricity generation is still very low: biomass and waste provided around 6\% of the EU's electricity generation in 2012, [13]. Biomass is used primarily in countries with extensive forest industries, where residues such as branches, wood chips and sawdust can be used to produce electricity and heat. Countries with large agricultural industries and industries that produce waste products that can be used as bio-fuels also have potential to increase their use of biomass.

The development of solid (wood), liquid (bio-fuel), and gaseous (biogas) bio-energy increase the volume of storable energy. Depending on their cost and the value of $\mathrm{CO}_{2}$, they can be used to produce electricity or to directly replace traditional fossil fuels. They are also one of the solutions to the increased storage demand.

\section{Waste-to-Energy}

Waste-to-Energy (WtE) or energy-from-waste is the process of generating energy in the form of electricity and/or heat from the incineration of waste. Waste (municipal solid waste-MSW, refuse-derived fuel-RDF, landfill gas-LFG) is taken as renewable energy source because it is continually replenished. The heat generated by burning wastes has other uses as well, as it can be used directly for heating, to produce steam or to generate electricity. Thermal technologies used to produce energy from waste include combustion (mass burn and RDF), while chemical processes include conventional and plasma-arc gasification and pyrolysis. RDF is the process of removing the recyclable and non-combustible parts from the MSW and producing combustible material. Figure 4 depicts the process of converting waste to energy where pollution control system is applied, [14]. Pyrolysis involves the change of chemical composition of waste in a complete lack of oxygen atmosphere, and the synthetic gas (syngas) produced during the reaction is converted to biodiesel and other liquid fuels. Conventional gasification uses a fraction of the air/oxygen that is generally needed to combust a given material and thus creates syn-gas. The plasma-arc gasification utilizes high temperatures $\left(2,200-11,000^{\circ} \mathrm{C}\right)$ to create syn-gas as well as high value sensible heat. An advantage of plasma gasification is a high temperature that can minimize air pollutants well below those of traditional WtE facilities, [15]. 


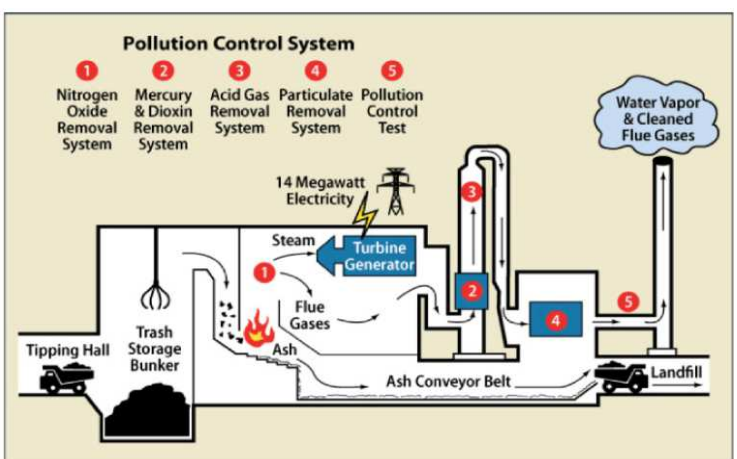

Figure 4: Waste to energy plant diagram, [14]
In many parts of the world, the way in which the waste is disposed is coming under increasing care and scrutiny. In the EU, Directive 2008/98/EC has provided a legal framework aimed at the whole waste cycle from generation to disposal, placing the emphasis on recovery and recycling, but favoring energy recovery over landfilling for wastes which cannot be recycled. In 2014 the EU Commission adopted a legislative proposal which aims at phasing out landfilling by 2025 for recyclable waste (including plastics, paper, metals, glass and bio-waste) in nonhazardous waste landfills, corresponding to a maximum landfilling rate of $25 \%$, [15].

There is currently a significant gap between the amount of residual waste (waste which has been through a recycling process to recover materials) being produced and the capacity to process that fuel domestically. Fortunately, thanks to excess capacity in a number of north European countries including Sweden, Germany and the Netherlands, there is a buoyant export market. Despite WtE occupying less than $6 \%$ of the total waste management market, the global WtE market is expected to reach US\$ 36 billion by 2020, [1]. Most of it is expected to be used for power generation in combined heat and power (CHP) plants.

\section{Fossil Fuels}

\section{Oil Fired Power Plants}

Oil remains the world's leading fuel, accounting for $32.9 \%$ of global energy consumption. Roughly $63 \%$ of oil consumption comes from the transport sector, [1]. Oil has once been used to produce electricity on a much larger scale than today. In utility-scale power plants it is mainly used as a supplement to low grade coal such as lignite. However, the oil based distributed generation is increasing, usually combined with production of heat, particularly where natural gas is not available. In that respect, an interesting dependence between oil and renewable exists. The deployment of renewables on a large scale, which would almost certainly require subsidies, could lead to low oil prices, leading to the need for even higher subsidies. An alternative would be higher taxes on conventional fuels or on their carbon content to make renewables economic, unless there were spectacular falls in their costs. Countering the problem with higher taxes would have to be international as, otherwise, cheaper oil would flow to areas where fossil fuels were not taxed.

Changes in the way how energy is produced define a risk for existing assets to end up stranded. But looking ahead, a growing number of primary resources, particularly coal, and possibly oil, may remain unused. Oil will still be needed for transportation providing over $60 \%$ of energy needs, but overall oil demand will flatten out. With stagnating growth potential in the oil sector and with coal likely to be of little importance by 2060 , there will be a shift in the discussion from stranded assets (predominantly enterprise owned) to stranded resources in oil and coal (predominantly state owned), [3]. This has the potential to cause significant stress to the current global economic and geopolitical equilibrium and will need to be part of a broadened carbon and climate dialogue.

Energy intensity reductions supported by primary energy substitution effects are set to increase at a faster rate than the demand increase. This therefore shifts the discussion from peak oil to peak demand with anticipated growth limited to only a $20 \%$ increase over the next 45 years, [1]. This will have significant implications for energy companies in terms of their ability to achieve their growth expectations, which will need to be factored into investment strategies.

Unconventional oil recovery accounts for $30 \%$ of the global recoverable oil reserves. Oil shale contains at least three times as much oil as conventional crude oil reserves. However, oil substitution is not yet imminent and is not expected to reach more than $5 \%$ by 2020 , [1].

\section{Natural Gas fired Power Plants}

Natural gas is the second largest energy source in power generation, representing $22 \%$ of generated power globally and the only fossil fuel whose share of primary energy consumption is projected to grow. Power generation reflects $40 \%$ of natural gas demand and will continue to be the largest driver in natural gas demand growth, fol- 
lowed by industrial and building use, which combined reflects $44 \%$ share of demand, [1]. In this way an increased use of natural gas, combined with decreased use of coal, will drive energy associated $\mathrm{CO}_{2}$ emissions from natural gas surpass those from coal.

The build out of natural gas plants is not as aggressive in Europe as it is in the US because of the availability of shale gas there. Europe is more aggressively decarbonizing than the US based on stronger development of RES (primarily wind and solar). There are areas of Eastern Europe that have coal development underway, but as time moves forward the coal will be a decreasing part of the mix with an increase in RES and natural gas. The natural gas-fired plants have public opposition as well, but compared to coal, natural gas projects have more of an opportunity to move forward: they are faster to permit and faster to build than coal plants.

Gas utilization for power generation will probably increase considerably in the future. Shale gas is one possible source of gas that is explored in parts of Europe, where exploitation is allowed. There are various deep changes in the gas market. Until the recent past, gas had an undisputed reputation, but now is in the same category as coal and oil. The distinctive advantage of gas, being the cleanest fossil fuel, is subject to erosion in the perception, although this differs significantly per region. In fact, natural gas has a meaningful and beneficial role to play in the energy mix, also in the foreseeable future. The big challenge for the power industry is to develop a relevant proposition for gas and gas infrastructure in the context of the energy transition. The impact of the current low prices has a more direct impact on investments in, for instance, liquefied natural gas (LNG) and shale gas, than on investments in infrastructure which tend to have a longer lead-time.

\section{Coal Fired Power Plants}

Coal still provides around $40 \%$ of the world's electricity. However, climate change mitigation demands, transition to cleaner energy forms and increased competition from other resources are presenting challenges for this sector. The coal production declined with $0.6 \%$ in 2014 and with a further $2.8 \%$ in 2015, the first decline in global coal production growth since the 1990s, [1]. Asia presents the biggest market for coal and currently accounts for $66 \%$ of global coal consumption. Failure to timely plan for replacement of decommissioned base-load power plants might pose a risk to energy reliability in some countries.

In spite of a growing public sentiment against coal, heavily covered by media outlets, the number of globally planned new coal generating units, defined as separate generating units at power plants, is growing, with 3,019 units planned which would deliver 1,554 GW of capacity. By comparison, 7,000 planned new units for wind will deliver 504 GW of capacity, while 4,174 planned solar units will be with 208 GW of capacity, 3,682 planned natural gas units with $568 \mathrm{GW}$, and 11,120 planned hydroelectric units would deliver $762 \mathrm{GW}$ of capacity, [16].

While fossil fuels will continue to have a significant role in the energy mix, contributing between half and two third of the energy needs in 2060, coal could potentially only represent $5 \%$ in the overall mix, [3]. The European coal power plants that are currently in use are old and will have to be shut down or refurbished for use in the next few decades. The thermal power plants in 2030 will consist of old base load plants, new gas combined cycles, some converted and new biomass units and new peak load plants. Regardless of how the rest of the system develops, large investments will have to be made in new thermal plants. The most urgent is to improve the efficiency of the complete chain of electricity generation from coal and lignite (methane collection, rising efficiency of generation toward very high efficiency (from $\sim 32 \%$ to $47 \%$ efficiency, [17]).

The fact of the matter remains that, until research can overcome the energy density and storage challenge that haunts renewable energy generation, it will continue to struggle to gain ground against the use of fossil fuel, unless the latter is hampered by law and regulation so as to make it unaffordable. Renewable enthusiasts often point to Germany as the great success story for renewables. However, at their power generation portfolio for 2014, wind and solar still accounted for less than 15\% of the energy production, Figure 5, [18]. In 2014, the gross electric power generation in Germany was $639.6 \mathrm{TWh}$, and total proportion of the electricity supply based on renewables (wind, PV, water, biomass, waste) accounted for $26.2 \%$, on lignite $25.4 \%$, on hard coal $17.8 \%$, on nuclear energy $15.8 \%$, and on natural gas $9.5 \%$, [18]. It appears that power generation from traditional sources (coal, gas, nuclear) was almost $70 \%$, of which $43.2 \%$ from coal alone.

\section{Nuclear Power}

Nuclear energy provides, after hydroelectric power, most of the world's carbon-free electricity. As of February 2016, in 31 countries 442 nuclear power plant units, with an installed electric net capacity of about $384 \mathrm{GW}$, are in operation and 66 plants, with an installed capacity of $65 \mathrm{GW}$, are now under construction in 16 countries. Twothirds (44) of the new nuclear power units currently under construction are located in three large countries: China, India and Russia, [1]. 


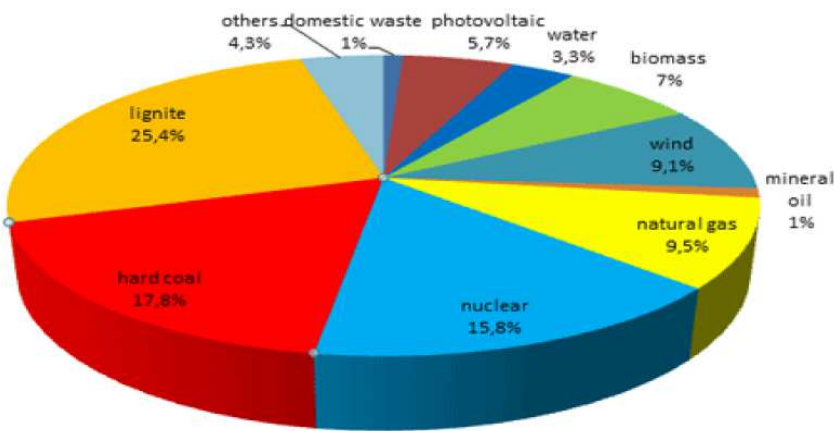

Figure 5: Electricity production by energy sources, Germany
Currently, there are more than 45 small modular reactors (SMR) designs under development and four SMRs under construction, [19]. The situation of nuclear power has changed following the earthquake and tsunami in Japan in 2011. Instead of being globally regarded as an acceptable technology option for the future, nuclear has faced early shutdown and been questioned in some countries.

The US EIA projects that total global nuclear generation will increase by $73 \%$ through 2040 , from 2,600 TWh in 2015 to 4,500 TWh in 2040. Figure 6 shows the projected nuclear generation by 2040, [20]. The non-OECD countries account for $86 \%$ of this increase, with China alone making up more than $54 \%$ of total growth.

As of 2015, China has

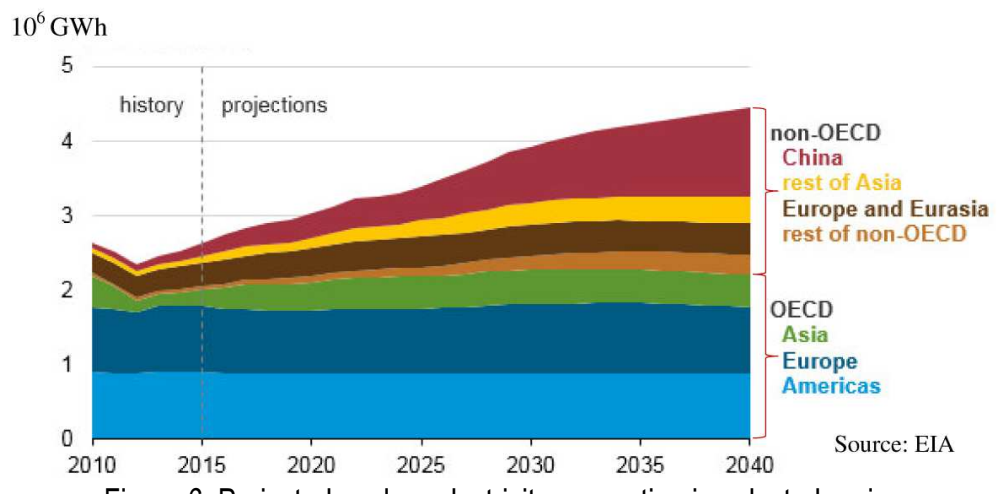
34 operating nuclear reactors, with a total capacity of $27 \mathrm{GW}$ and additional 22 GW (20 reactors) under construction, [20]. China is expected to increase nuclear capacity to nearly 90 GW by 2025 and, by 2032 , to surpass the USA (the country with the most electricity generation from nuclear) and produce more than 1.2 thousand TWh of electricity annually by 2040 , [21]. The nuclear generation in the non-OECD Asia

(specifically China and India) surpassed OECD-Asia (Japan and South Korea) in 2012. Although South Korea is expected to increase its use of nuclear power and Japan is expected to restore some nuclear capacity, few capacity changes in those countries are anticipated after 2020. Meanwhile, nuclear power growth in China and India is expected to continue through 2040, with China dominating growth in the region. Both OECD Europe and OECD Americas (including the USA) are expected to maintain current nuclear generation levels through 2040. By 2028, nuclear generation in non-OECD Asia is expected to exceed both OECD Europe and OECD Americas.

\section{TECHNOLOGICAL CHALLENGES}

\section{Energy Storage}

Distributed energy storage is the next step in reducing the need for centralized dispatchable fossil fuel plants, which are currently required to balance the intermittent supply from renewables. Energy storage technology is particularly coupled to the wind and solar technologies. The various technologies of electricity storage are characterized by their power output, but also by the amount of energy that can be stored. On a grid scale, electricity storage is most frequently accomplished with pumped water storage, [22]. When excess electricity is available from the grid, water is pumped from a lower reservoir to a higher reservoir, and allowed to flow back down and generate electricity. However, the most commercial interest is shown in battery storage technology.

Renewable energy is driving opportunities for energy storage across all global markets, [23]. The costs of new storage technologies will fall as production volumes increase so that, with the cost of capturing and storing energy coming down, their deployment across the world will increase. However, the surge in demand required to ramp up battery cell production and bring down costs may not take place as rapidly as anticipated because costs 
remain too high for mainstream adoption. Further, because the power industry is anticipating lower costs in the future, large scale investment in storage technology is relatively limited.

Energy storage has been characterized by rapid change, driven by reduced costs (especially batteries) and increased industry requirement to manage system volatility. At the end of 2015, the global installed storage capacity was $146 \mathrm{GW}$, consisting of 944 projects. There are already around 25000 residential-scale units in Germany alone. The projections suggest a global storage market of $1.4 \mathrm{GW} / \mathrm{y}$ by 2020 , with strong growth in electromechanical technologies in particular, [1].

The majority of the electrical (capacity) or chemical storage may store for a few hours with a maximum of 7 hours. It is the same for most pumped hydro storages, with some exceptions of up to 20 hours, [24]. A low wind period may last several days and sometimes more than one week. The low solar production in winter lasts for several weeks. For such longer need of storage, it is possible to use more bio-fuels and to develop power to gas technology to produce hydrogen and then methane in combination with $\mathrm{CO}_{2}$, [23].

Although the energy storage benefits the grid system in terms of the intermittency of the power supply and provides greater control of the network, their integration significantly increases the total lifetime cost of power projects. Additionally, energy storage typically has round-trip efficiencies of between $70 \%$ and $95 \%$, so will discharge less energy back into the system than it can absorb, [23]. Limited utility-scale experience of energy storage in renewable energy applications also raises uncertainties and risks, such as system failure causing loss of revenue for power plants.

\section{Carbon Capture and Storage}

Carbon capture and storage (CCS) technologies remove $\mathrm{CO}_{2}$ gas from the emissions and sequester it in the ground or ponds. CCS has a potential to substantially decrease the impact of fossil fuel combustion for the electricity system. The Paris Agreement of December 2015 has identified an ambitious goal to limit emissions of $\mathrm{CO}_{2}$ and other 'greenhouse' gases in order to keep global warming below $2{ }^{\circ} \mathrm{C}$. As it currently stands, $41 \%$ of global $\mathrm{CO}_{2}$ emissions are produced by the energy sector, followed by transport with $23 \%$, so that many countries are working towards decarbonizing energy supply with more environmentally friendly means of energy production, [25].

CCS is central to prospects for the continued use of coal if international commitments to a lower-carbon future are to be met. However, several factors may constrain the rate of deployment of CCS. As the world tackles the challenges of global warming, fossil fuel companies can and must acknowledge the global political consensus and act to preserve climate change. A substantial transport and storage infrastructure will need to be created and the public perception will impact the permitting process of CCS development. There is also a need to develop confidence in the geological processes that will determine the long-term security of the stored $\mathrm{CO}_{2}$. In addition, cost, efficiency and water consumption of the CCS technology needs to be improved.

The future of CCS crucially depends on public understanding and agreement and adequate carbon prices. There are 22 large-scale CCS projects currently in operation or under construction around the world, with the capacity to capture up to 40 million tons of $\mathrm{CO}_{2}$ per year, [1]. The world's first large-scale application of $\mathrm{CO}_{2}$ capture technology in the power sector commenced operation in 2014 in Canada. Some new CCS approaches, such as an enzyme-based carbon capture process, continue to advance. When applied at large scale, it would reduce cost of carbon capture to below $\$ 40$ per ton (including compression) or below $\$ 30$ per ton (without compression), [26].

Therefore, CCS is considered to be an essential element of any low carbon energy future. Unfortunately, some major fossil fuel companies still neither make a break from climate denial or disinformation, nor are planning for a world free of global warming pollution, [27]. In order to succeed, CCS needs more institutional support, because policy is the main issue, not technology.

\section{Combined Heat and Power Generation}

Traditionally, combined heat and power (CHP) plants have been owned and operated by industrial and institutional owners who have enjoyed the efficiency benefits of onsite CHP. With lessons learned from the power supply security issues, industrial and institutional owners are more focused on distributed generation, including CHPs, as means of obtaining a reliable, resilient and efficient source of energy. CHP generation (cogeneration) gets today an impetus from both energy efficiency and environmental considerations. Making good use of the heat generated, and otherwise discarded, at thermal power generation is the basis for CHP technology. CHP plants maximize fueluse efficiency by feeding that heat to supply the needs of buildings, district heating systems or industrial processes. The heat customers that are also able to self-produce electricity can help to balance intermittent generation.

Inherently high efficiency of CHP delivers economic and power system benefits to users and grid operators. Much of today's innovation around cogeneration, which was traditionally fuelled by coal and latter by natural gas, is 
about identifying waste heat sources and renewable fuels, even for large industrial applications. Slightly different, and usually smaller in scale, is technology used to generate electricity from a range of industrial sources of 'waste' heat, or from renewable heat sources. Devices such as the organic Rankine cycle turbo-generators are used in more than 300 installations in 34 countries, [28]. Recently developed installations make use of geothermal heat sources for steam and power production. An interesting solution, called 'green machine' as presented in Figure 7 , is based on the organic Rankine cycle (ORC) and the use of waste heat, [29].

Although CHP efficiency benefits are widely understood, power utilities are not fully embracing CHPs due to concerns associated with realizing economic benefits, restructuring of the billing and tariff structures, as well as

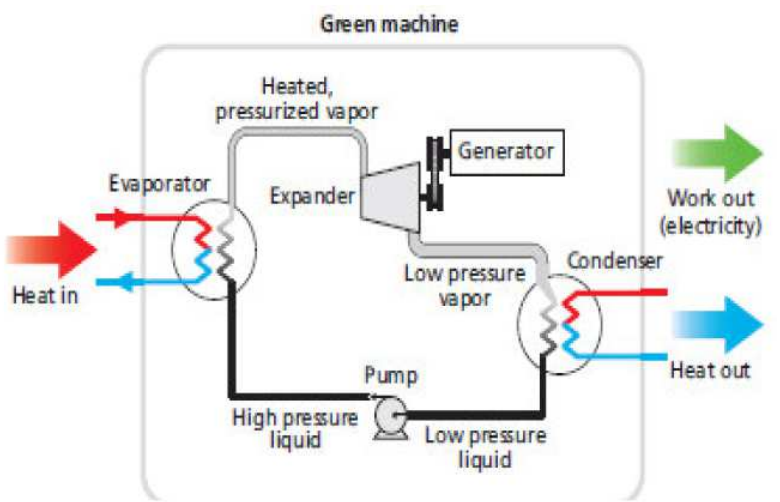

Figure 7: A 'green machine' - CHP plant based on ORC technology and waste heat honoring existing agreements with their regional transmission organizations. When the power utility is the owner/operator, the CHP costs should be compared to the potential revenue streams from the sale of marketbased power and thermal energy to the customer(s). From this comparison, the overall economic return on investment should be determined.

Projects with adequate net present values of free cash flows will be identified as potential CHP sites that would then require a detailed financial analysis for final selection. In the electric utility industry, common ratemaking approaches associated with CHP services center around the transactional arrangement where the utility owns and operates the CHP facility. If compensation for power is based on actual avoided costs, no margin impacts are expected. However, for a utility with excess capacity over the near and longer term, the avoided costs are based on energy costs alone and the margin potential depends on the heat rate differentials between avoided costs at system marginal heat rates and the CHP facility heat rate times any difference in fuel costs per unit of heat energy.

\section{Distributed Generation}

Distributed generation (DG) is an approach that employs small-scale technologies to produce electricity close to the end users of power. DG technologies often consist of modular (and sometimes renewable-energy) generators, and they offer a number of potential benefits. In many cases, distributed generators can provide lowercost electricity and higher power reliability and security with fewer environmental consequences than can traditional power generators. Local energy generation offers significant advantages over centralized generation. Marketbased DG structure would provide customers with energy choices and enable multiple DG technologies to offer the greatest competitive value possible to the grid, such that non-participant customers may benefit from distributed energy deployment.

Several factors differentiate distributed energy technologies from their utility-scale counterparts, and provide the justification for incremental compensation beyond utility-scale project competitive pricing levels. While many utilities are embracing the shift to renewable energy, others are slow to change due to significant investments in conventional generation resources and a concern that over-reliance on intermittent renewable generators such as solar photovoltaic and wind could jeopardize reliability, [30].

\section{Smart Grids}

\section{Community Micro-Grids}

The Internet and networked technologies have changed many aspects of the power sector. Increased digitization, through devices such as smart meters, continues to create efficiencies and offers operators the opportunity to improve management of production. Upstream, digital technologies are used for production optimization, reliability and preventive maintenance, and supply chain planning analytics. Downstream, the shift to digital is being realized through supply-demand matching smart grids and new approaches to networking operational systems. Applications of digital technologies further downstream include trading activities and marketing and business insights. 
The power system, built on century-old technology and approaches, was designed to deliver electricity from large, remote power plants across significant distances to places where electricity is actually used. Although locally sited renewable energy generation has become economically competitive with such centralized generation and offers a superior approach for a vastly improved power system, utility executives and policymakers remain reluctant to embrace local renewables due to fears that the existing power system cannot reliably integrate distributed energy generation. These grid reliability concerns have effectively limited local renewables to providing no more than $10 \%-15 \%$ of peak power needs. To overcome this reluctance, the community micro-grid demonstrates the technical and economic feasibility of higher penetrations of local renewables.

The re-engineering process from current networks to smart energy networks encompasses a complex range of issues covering market design, organizational, regulatory and technical issues. Community micro-grids prove local renewables provide a reliable and cost-effective foundation for a modern grid. A community micro-grid is a coordinated local grid area served by one or more distribution substations and supported by high penetrations of local renewables and other distributed energy resources (DERs) such as energy storage and demand response, Figure 8, [31]. Such community micro-grids represent a new approach for designing and operating the electric grid. They

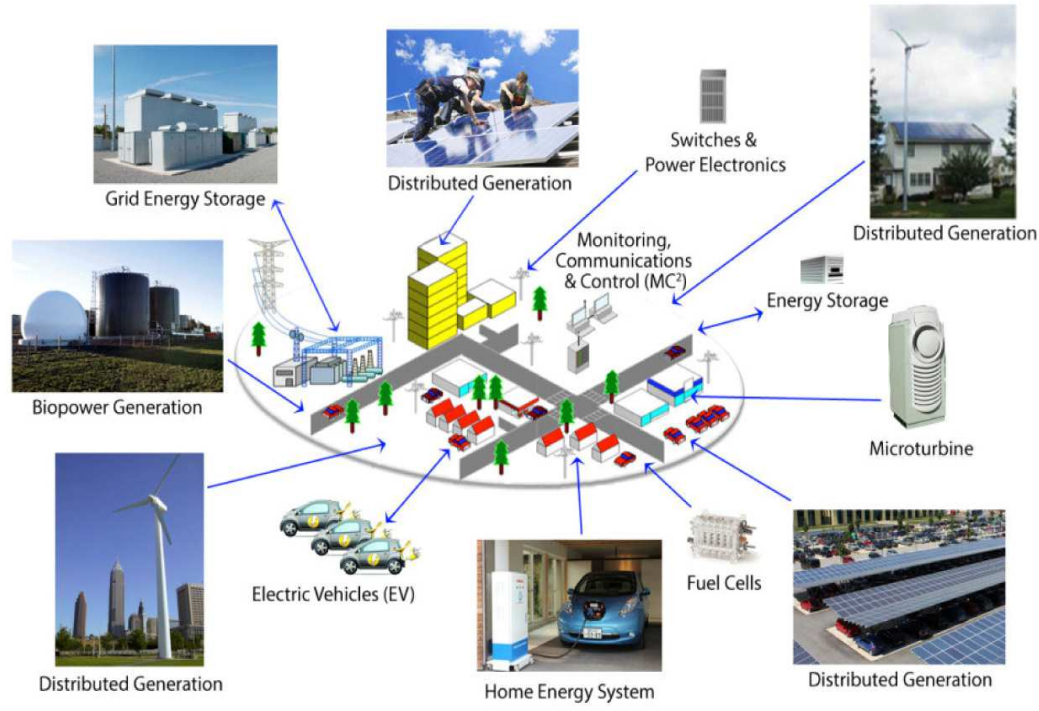

Figure 8: A community micro grid architecture rely heavily on DERs to achieve a mo-re sustainable, secure, and cost effective power generation while generally providing renewable energy - driven power backup for the prioritized loads over an indefinite duration. Substation - level foundation of a community micro-grid ensures that the approach can be readily extended throughout a utility's service territory and replicated across utilities.

Community micro - grid leverages high penetrations of local renewables and other DERs to achieve desired level of grid reliability, power quality and resilience, as well as creates a more sustainable, reliable, secure grid. It reduces dependence on vulnerable, inefficient, and expensive remote generation and associated transmission infrastructure. For some time, computing, data processing and storage have been migrating to the 'cloud', and now people are talking about the 'energy cloud', where DERs, making use of intelligent devices, storage and a smart grid, connect all manner of distributed loads and resources to meet customers' energy service needs. As a concept, the 'energy cloud' represents a wide range of technical, commercial, environmental, and regulatory changes that are transforming the traditional utility model for energy provision.

\section{Virtual Power Plants}

On-site renewable power has many different alternatives depending on the company's goals from rooftop solar energy and micro wind turbines to biomass cogeneration plants. The temporary power that can plug the gaps in renewable energy intermittency and disruptive technologies has revolutionized many power industries, creating new business models built around customers. One of such models is the concept of virtual power plant (VPP). The VPP is a modularly designed software suite which connects, coordinates and monitors decentralized power plants, energy storage facilities and controllable loads via a common intelligent control center, Figure 9, [32]. In doing so, it can act within various energy markets as would a conventional power plant. 


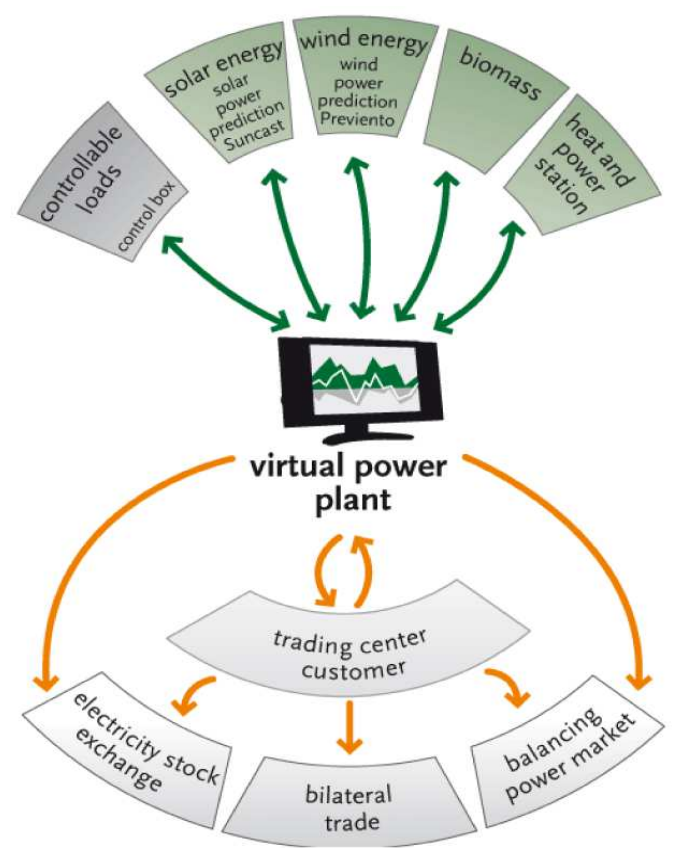

Figure 9: Virtual power plant scheme

The VPP offers a variety of services to power plant operators, industrial consumers, public services, electricity suppliers, power brokers and power grid operators. Embedded hardware and software will form the glue that binds the 'energy cloud' together and enable its operability. VPP, as a network of decentralized, medium-scale power generating units such as biomass plants, CHP units, the wind farms and solar parks, as well as flexible power consumers, relieves the load on the grid by smartly distributing the power generated by the individual units during periods of peak load.

VPPs, as the system within the 'energy cloud' landscape, proves to be a reliable source of electricity that can be very competitive to the central power plants operating at the utility level, [33]. In a VPP the power influx from decentralized and fluctuating renewable energies into power grids that were built for traditional power plants poses a challenge. But renewables can address this challenge themselves thanks to smart grids and responding to energy consumers' demand, so that a world in which $100 \%$ of the energy comes from renewables may no longer be a daydream.

The combined power generation of the units in the VPP is sold by a single trader on the energy exchange. As the result, VPPs gradually take over the role of traditional power plants by selling their output on the wholesale markets and assuming responsibility for the balanced grid. The interconnected units are partly operated through the central control room of the VPP, but remain independent in their operation and ownership.

In the burgeoning decentralized model, companies create a platform so individuals can own the valued goods or services that are produced and potentially sold. As with the famous Uber and Airbnb shared economy concept for lodging outside hotels, and for private transportation without taxis ([34]), many clean energy technologies, such as micro-grids and solar PV, are forcing a previously entrenched industry to pivot, placing customers at the center. An upswing of community micro-grids and rooftop solar panels is catalyzing the electricity sector's trend toward decentralization. VPPs makes decentralized generation to offer possibility for people to have more choice in terms of investment and potential profitability, as it creates a platform that enables owners to directly sell electricity and generate profits. As micro-grid and solar PV technology already exist and operate successfully, VPPs are enabling ways to take better advantage of these resources and empowering people to veer from the traditional provider of services, as well as allow them to make money in ways that did not exist until recently.

\section{Cyber Security Concerns}

Cyber risk presents a unique concern in the power sector because an attack on the infrastructure has the potential to cause a massive operational failure of an energy asset. Large centralized infrastructures are especially at risk due to the potential 'domino effect' damage that an attack on a nuclear, coal, or oil plant could cause. The changing energy architecture, including the expansion of decentralized renewable generation assets and the smart grids to improve the management of electricity, create an increased number of entry points for cyber intruders. Therefore, introduction of 'smart' solutions will require cyber security and power system communication systems to be dealt with simultaneously, [35].

While remote control is intended only for authorized operators and third party suppliers, it can just as easily be accessed and exploited by unauthorized users with malicious intentions unless safeguards are imposed. Ever increasing levels of cyber threat are contributing to a new reality for the power plants. With increasing systems integration, resilience is no longer just about building systems stronger and returning single assets to full operation after a disruptive event. When interdependent systems are blacked out by cyber attack, the system as a whole is at risk of being deadlocked. Black-starting capability, decentralized decision autonomy and local empowerment have become key concepts of a new 'soft resilience' approach as opposed to the traditional 'hard resilience' practice of simply building systems stronger. 


\section{Innovative Power Generation Schemes}

\section{Fuel Cell Power Plants}

Contrary to conventional power plants, a fuel cell $(F C)$ power plant generates power in a non-combustion process and delivers heat and electricity virtually absent of pollutants, making it a milestone for the green energy of the future. Today the capacity ranges from kilowatt to over megawatt sizes. In terms of technology and environmental protection, fuel cells represent a promising alternative to conventional combined heat and power plants. In comparison with other decentralized technologies such as gas turbines, they use fuel sources far more efficiently.

For demonstration of confidence in the FC technology, a US company has received government funding to develop a fuel cell-driven on-site power plant, Figure 10, [36]. The facility is intended to demonstrate the

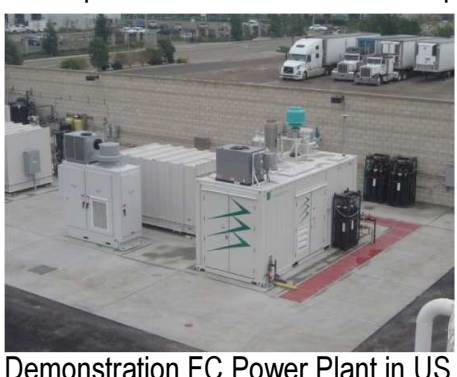

Demonstration FC Power Plant in US

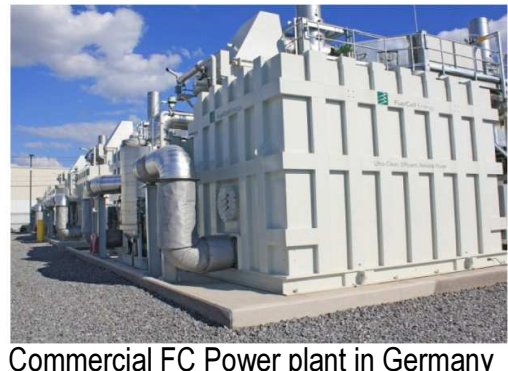

Commercial FC Power plant in Germany

Figure 10: Fuel Cell Power Plants trigeneration capabilities of the FC technology for industrial ap-plications. This sub-MW trigeneration FC power plant located at a manufacturing facility generates around $135 \mathrm{~kg}$ of hydrogen per day for manufacturing process-ses, as well as electricity and heat, thus replacing both hydrogen that was purchased and delivered by truck, and power that was taken from

the power grid.

Once commercially available, the FC power plant technology is expected to produce hydrogen that will be priced competitively, from $\$ 5-\$ 7 / \mathrm{kg}$, or lower with increased production volumes. In addition, on-site hydrogen generation avoids the costs and pollutants associated with transportation while enhancing the reliability of supply, [36].

The first European FC power plant of $1.4 \mathrm{MW}$ size is operating in Germany, where it provides clean energy for a materials production industry, Figure 10 . While operating, this $\mathrm{FC}$ power plant is able to avoid $\mathrm{CO}_{2}$ emissions by approximately 3,000 tons per year, which corresponds to the $\mathrm{CO}_{2}$ emissions of approximately 250,000 family cars per 100 kilometers, [37]. This FC power plant, as the only one of its kind in Europe to date, was installed in only nine months as a joint project by a power utility and a manufacturing industry. They have entered into a longterm energy partnership to offer high-performing clean FC technology to customers in energy-intensive sectors.

The distributed generation by the use of the FC power plants in a non-combustion process is meant to replace heat and electricity from conventional heat and power plants, thus avoiding harmful pollution from these plants. Together with RES, fuel cells are expected to offer a carbon free future.

\section{Hybrid Power Plants}

Hybrid power generation systems provide a source of power that is both clean and consistent. They offer solutions to many problems and concerns faced by power producers, grid managers and consumers. Hybrid power plants can provide power on demand and be an effective tool in integrating more renewable resources into the grid while providing firm capacity to back up those variable resources.

For example, in a hybrid system, clean but intermittent solar power can be paired with a reliable generator fueled with natural gas. Also, waste wood can be co-fired with waste coal to lower emissions. Wind power can be coupled with compressed air to create a reliable source of power for remote areas with limited transmission. Some hybrid projects combine diesel generator sets with solar PV technology. Hybrid power plant may use geothermal power and solar power, both PV and solar thermal, to produce electricity, [38]. There is a concept that combines coal gasification and fuel cells, where the syn-gas produced from coal would react with oxygen to produce electricity, being twice as fuel efficient as a conventional coal-fired power plant because combining them in a single plant would allow the two components to exchange heat with minimal energy losses.

Despite the obvious benefits, there are several drawbacks that create a concerning level of risk for hybrid power projects. The benefits of renewable systems coupled with either a generator or energy storage depends greatly on the value of the firm capacity. If renewable power represents a small percentage of a system's load, other generators in the system can easily make up the difference when the wind does not blow or the Sun does not 
shine. Under such situations, the firm capacity provided by the hybrid system is usually poorly valued. Also, in remote locations, the power cannot be easily sold due to a limited number of potential buyers.

\section{ENERGY AND WATER NEXUS}

\section{Water for Energy}

There is a critical linkage between water and energy and the impact of both on climate change. Water is used in energy production and supply, and, in turn, energy is used for producing (e.g., by seawater desalination), pumping, moving and treating water. In recent decades, the combination of more users with more uses of water, has transformed the traditional linkages between both energy and water systems, which have grown more complex and interdependent, so that water must be viewed as a complex vulnerability of the energy system and vice versa.

Water is needed throughout the energy sector. It is used in energy production and conversion, as well as in other processes, such as the refining of energy source products. The water use in a range of energy processes, including crude oil, natural gas, coal, uranium, and biomass, vary considerably. Although oil presently accounts for as much as $34 \%$ of the global primary production, and decreasing to $22 \%$ by 2050 , it accounts for only $10 \%$ of water consumption in primary energy production now, rising to $18 \%$ in 2050 . This is mainly due to the increasing share of nonconventional oil in total oil production, from $1 \%$ now to $12 \%$ in 2050 and its higher water consumption, [39]. Today almost $90 \%$ of freshwater used to produce primary energy is for the production of biomass, which accounts for not even $10 \%$ of total primary energy production. This relationship will change over time. In 40 years, the share of freshwater used to produce biomass will decrease to less than $80 \%$, while at the same time the share of biomass in the total primary energy production will diminish to less than $5 \%$. Water consumption to generate electricity will more than double over the next 40 years, [40].

The future water needs of energy production and conversion can probably be met. However, other uses, in particular for agriculture, are already stressing the supply of useable water now, and this is likely to increase in the future, so that water must be available for all these uses, including energy production and conversion. As energy resources are stretched, increasingly unconventional sources become attractive, and many of these (e.g., oil shale) require large amounts of water, thus further stressing the current and projected systems.

\section{Water Recovery}

Recovering heat and water from flue gas can reduce water usage and boost power plant performance. However, until now, there has been no practical commercial technology available for recovering both waste heat and water from the power plant flue gas. Heat is removed from the flue gas through the use of economizers and air preheaters, but condensing water remains a limitation in how low the temperature can be taken. Condensing flue gas moisture by simply removing heat in a heat exchanger is a problem because a large surface area is required and equipment corrosion often occurs because of the acidic condensate. The recovered water needs further treatment before it can be used for any other processes due to the high acidity and other contaminants that may present in the water.

A promising technology condenses water and recovers heat from flue gas. An innovation, called the transport membrane condenser (TMC), based on a nano-porous ceramic membrane device, condenses water and recovers heat from flue gas, Figure 11. The TMC technology can be particularly beneficial for coal fired power plants that use high moisture coals and/or a wet flue gas desulfurization (FGD) for flue gas cleanup. For a coal fired power plant equipped with a wet FGD unit, flue gas exits at up to about $80^{\circ} \mathrm{C}$, with nearly $100 \%$ relative humidity and contains up to about $40 \%$ in volume of water vapor. If 40 to $60 \%$ of this water vapor and its latent heat could be recovered and reused, the plant thermal efficiency could be significantly improved while providing a water recovery

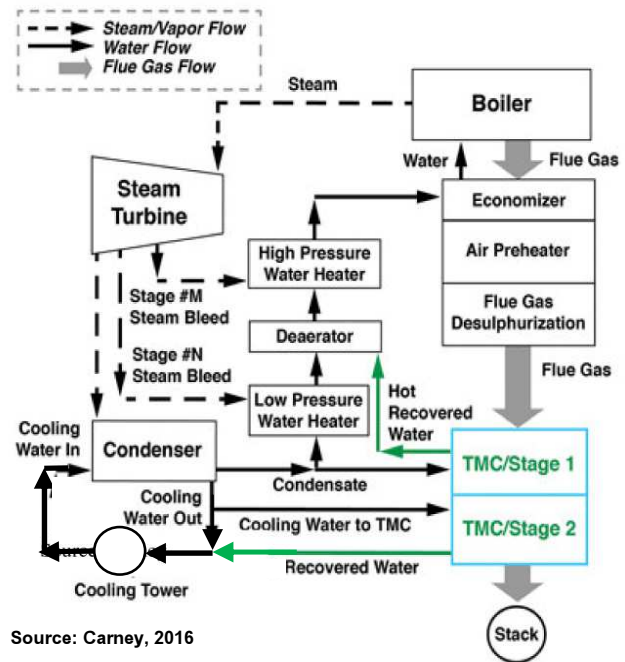

Figure 11: The TMC concept for water recovery 
benefit. The TMC technology for power plant application is aimed at optimizing heat and water recovery in a two stage design, Figure 11, [41]. For the first stage, TMC will use condensed steam from the steam turbine in the tubes. The condensed steam is at $70^{\circ} \mathrm{C}$ to $90^{\circ} \mathrm{C}$, which is sufficiently cool to provide a driving force for water transport across the membrane. The recovered water and heat are entered back into the steam cycle downstream of the first low-pressure feed-water heater, thus requiring less steam to heat. For the second stage, the TMC will recover a larger part of water from the flue gas and add it into the plant cooling water stream.

The efficiency improvement achieved by the TMC technology is about 0.7-0.8 and about $2 \%$ of makeup cooling water is saved, [41]. Challenges to more widespread use of this technology are the current low cost of energy and water. Even with these low prices, several applications of the TMC are already cost competitive with a quick return on investment of less than two years. When/if the TMC technology is commercialized, thick clouds of condensing water exiting a power plant stack will become a less common feature at thermal power plants because the majority of heat and water that create them will no longer escape into the atmosphere. Instead, they will be used to reduce water consumption, increase plant efficiency, and lower the costs.

\section{ECONOMIC CHALLENGES}

\section{Investments in the Energy Sector}

Investments in the energy sector face major challenges. They fell globally by $8 \%$ in 2015 , but robust investment continued in renewables, electricity networks and energy efficiency. Energy investment worldwide in 2015 amounted to $\$ 1,800$ billion (of which $30 \%$ in RES and energy efficiency), down from $\$ 2,000$ billion in 2014 , largely due to a $25 \%$ drop in oil and gas investments which resulted from cost reductions triggered by lower oil prices, [42]. The year 2015 had been the lowest in history for new oil and gas sector projects, and discoveries of new oil reserves had been the lowest in 60 years. China topped the list of energy-investing countries, spending $\$ 315$ billion in 2015 . Next is the US with investment of $\$ 280$ billion, followed by Europe ( $\$ 140$ billion), Russia ( $\$ 85$ billion) and India ( $\$ 65$ billion), [43].

Actual spending on renewables remained flat. The RES, led by wind, constitute around $70 \%$ of all power investments today. Even though investment in RES in the last years has been more or less flat, generation from renewable power sources increased substantially, more than $30 \%$, which means RES are becoming more and more economic, and the returns more strong. In 2015, RES generated more power than the total amount that the world consumed. But challenges remain, chiefly around intermittency and grid integration. Investment in energy storage, which could accelerate RES integration, has increased by a factor of 10 over the past years, but while the storage sector is strong and promising, it still makes up only $0.4 \%$ of total energy sector investment, [42].

Investment in gas-fired power generation capacity fell by $40 \%$ in 2015 , while investment in coal-fired capacity grew by $25 \%$, largely in Asia. In China, where the government is pushing strongly for renewable energy, nuclear power and energy efficiency, a significant part of the nation's coal-fired power capacity may remain unused. In India and Indonesia, however, the International Energy Agency (IEA) expects coal power capacity to become a larger part of the generation mix. In 2015 a record number of nuclear power capacity additions amounted to a total of $10 \mathrm{GW}$, the highest number in 10 years and totaling more than $\$ 20$ billion in investment, [43]. Nuclear power was added largely in China, but also in Russia and Korea. The main challenges of high up-front costs and public concerns continue to affect this sector.

\section{Levelised Costs of Electricity}

To fairly compare renewable to conventional power generation, the levelised costs for both base-load fossil fuel thermal and nuclear power stations, and a range of renewable power generation, including variable wind and solar sources, must be calculated. The levelised cost of electricity (LCOE) calculations is based on a levelised average lifetime cost approach, using the discounted cash flow method. The LCOE calculations use a combination of generic, country- and technology-specific assumptions for the various technical and economic parameters, [22]

Figure 12 shows a comparison of the discounted electricity generation costs (EGC) calculated by the IEA ([43]) at $10 \%$ discount rate by using data for 181 plants in 22 countries. This total includes 17 natural gas-fired generators (13 combined-cycle gas turbines and 4 open-cycle gas turbines), 14 coal plants, 411 nuclear power plants, 38 solar PV power plants (12 residential scale, 14 commercial scale, and 12 large, ground-mounted) and 4 concentrated solar thermal plants, 21 onshore wind plants, 12 offshore wind plants, 28 hydro plants, 6 geothermal plants, 11 biomass and biogas plants and $19 \mathrm{CHP}$ plants of varying types. This data set contains a marked shift in favor of renewables in 2015 compared to the 2010, indicating an increased interest in low-carbon technologies. LCOE values are calculated at the plant level (bus-bar), and therefore do not include transmission and distribution 

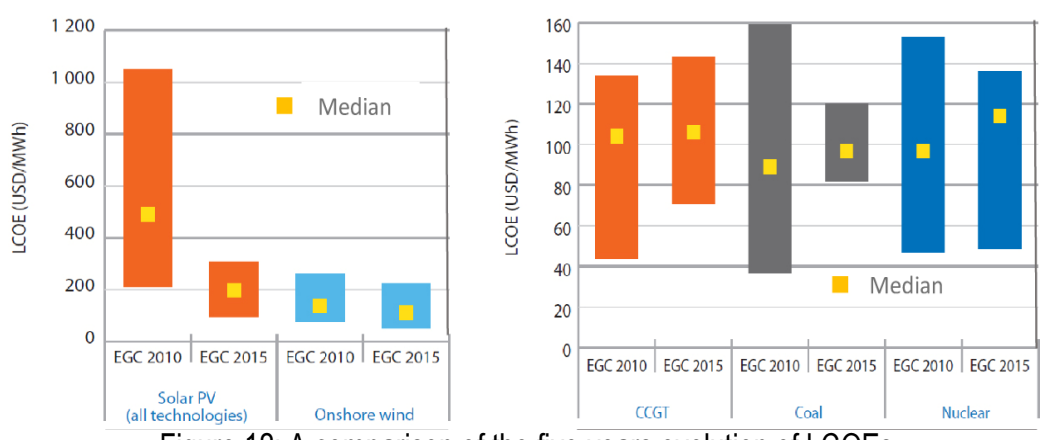

Figure 12: A comparison of the five years evolution of LCOEs for major power plant technologies

costs. Similarly, calculation of LCOE does not capture other systemic costs or externalities beyond $\mathrm{CO}_{2}$ emissions at a cost of 30\$/ton, [43].

A wide range of LCOE variations in Figure 12 comes from different conditions in each of 22 countries considered, [43]. As the discount rate of $10 \%$ may be considered high, particularly so for the most capital-intensive technologies, calculation of LCOE was done also for $3 \%$ and $7 \%$. To demonstrate the impact of discount rate on the LCOE values for renewable technologies in a single country (Austria), as well as the LCOE components (construction, operation and maintenance, fuel and CHP credit where applicable, as well as decommissioning costs), calculation was made for solid biomass and biogas CHP, onshore wind, commercial rooftop PV solar, and run-of-river small hydro power plant technologies, using all three $(3 \%, 7 \%$ and $10 \%)$ discount rates. Figure 13 shows to what extent the LCOE for these technologies depends on the cost of capital they require, [43].

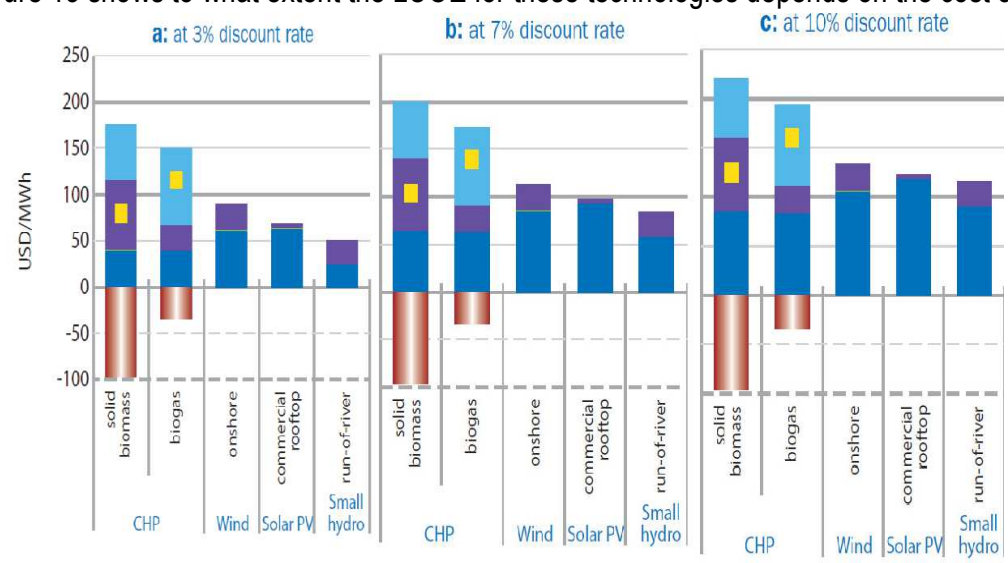

Figure 13: The LCOE calculated for RES in Austria at

(a) $3 \%$, (b) $7 \%$ and (c) $10 \%$ discount rates

New realities are increasingly characterized by growing zero marginal cost supply, low entry barriers, greater focus on decentralization and local empowerment, digitalization of technology, more flexible and rapid pay back solutions, increasingly active investors and servicing of emancipated consumers. These may change the relative LCOE values for different technologies in the future. For example, IEA shows that by 2030 onshore wind will be the second cheapest, while LCOE for offshore wind finds itself as the most expensive of all power generating technologies, even if its load factor is far better than on shore wind, [43].

\section{Cost Competitiveness}

Electricity is the fastest growing final form of energy, and yet, despite its increasing relevance to decarbonisation efforts, the future composition of the power sector remains uncertain. As policy makers work to ensure that the power sector is reliable and affordable, while making it increasingly clean and sustainable, it is ever more crucial that they understand what determines the relative cost of electricity generation using fossil fuel, nuclear or renewable technologies. The world currently gets about $80 \%$ of its energy supplies from fossil fuels because these sources generally provide energy at the lowest cost, [44]. However, the cost advantage of fossil fuels over RES has been decreasing in recent years, and certain renewables can already compete with fossil fuels solely on financial terms. Renewable energy costs are expected to decline further in the future, while fossil fuel prices will likely rise. Thus, even without policies to promote a transition toward renewables, economic factors are moving world in that direction.

Renewable solar and wind energy sources have low operating costs: once generating facilities are built, there is little additional cost for producing energy each year. While this is an operating advantage over fossil fuels, 
it comes at the cost of higher capital expenditure. Building a renewable energy plant is similar to building a fossil energy plant plus buying all the fuel that the fossil plant will use over its lifetime. Also, various studies of energy externalities suggest that, if the price of all energy sources included externality costs, a transition toward renewables would already be much further along, [45]. So, while fossil fuels may currently have a cost advantage over renewables based solely on market prices, if externalities were included, several renewables would likely become the most affordable energy sources, in particular on-shore wind, geothermal, and biomass energy. Similarly, the cost advantage of oil in transportation would likely disappear if externalities were fully accounted for in the price. These facts imply that there are good economic reasons to promote a transition towards renewables.

The costs of generating electricity from renewables, particularly from PV solar, are falling from these in 2010, Figure 14, [1]. Recently, several US utilities have announced solar power purchase agreements for 4 US cents per $\mathrm{kWh}$, while 25-year power purchase agreement reportedly coming in as low as 3.7 US cents per kWh with an option to extend the agreement to 40 years, [7]. Wind turbine prices have fallen by almost a third since 2009 (wind is now one of the most competitive sources of electricity available with some projects now delivering electricity for as little as 4 US cents per kWh), and wind power costs are expected to decline even further, [7].

International renewable energy agency (IRENA) declares that the average electricity costs could fall by $35 \%$ for offshore wind and $26 \%$ for onshore wind by 2025 , [46]. The fact remains that wind is one of the least-cost options in many markets for new power generation, and this is even before factoring fossils in environmental and health costs. IRENA estimates that doubling the global share of renewables by 2030 would save up to $\$ 4,200$ billion annually by avoided expenditures on air pollution and climate change, [46].

While further cost decreases are likely, the

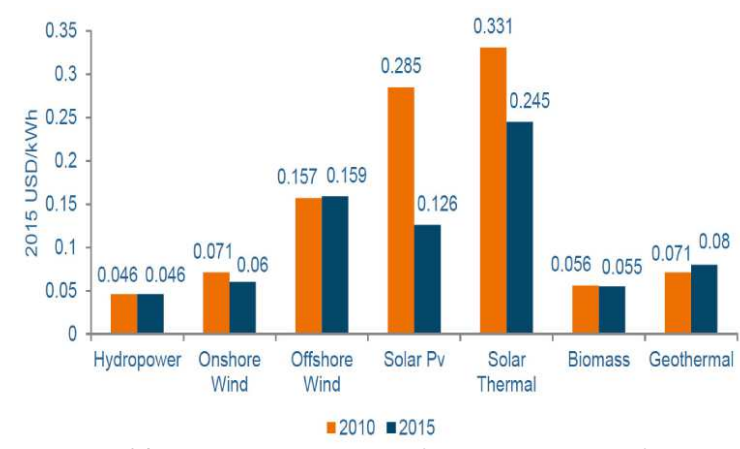

Figure 14: Five year evolution of generation costs from RES future costs will decline more slowly than in the past. Besides decreasing in cost, solar PV and wind cost variation will decrease. Thus the future prices for renewable energy are expected to be more predictable, which is not the case for fossil fuels. While renewable energy costs are decreasing, future market prices for renewable energy will not necessarily be less than historic fossil fuel prices. Current market designs and business models are unable to cope with these new realities, and will require entirely new skills-sets, business models and financing solutions.

Cost challenges for producing electricity based on renewable energy include their intermittency and capital intensity. By their nature, most renewable energy supplies cannot be matched to demand as easily as fossil fuels. To some extent, demand is predictable and fossil fuel plants can be scheduled to start and stop at times of the anticipated demand change. Also, hydropower may be regulated to accommodate demand, and biomass is available to burn on demand, while geothermal energy is the most constant RES and can be started and stopped on demand. However, solar and wind power do not have this character, and a complete transition from fossil fuels to renewable energy is likely to take many years.

\section{ENVIRONMENTAL CHALLENGES}

If the only issue were fossil fuel availability, it would not necessarily be a problem for society to take a long time transitioning to renewable energy. However, the combustion of fossil fuels causes environmental pollution and climate change, and waiting until fossil fuels are exhausted to deploy renewable energy sources might be catastrophic for civilization, [19]. This is an argument for internalizing the expected costs of pollution and climate change into the price of fossil fuels. Addressing climate change issue suggests that this needs to happen sooner rather than later, [45].

\section{Climate Change Mitigation}

The ambitious agreement reached at COP 21 in Paris has increased the momentum behind the global transition to low-carbon energy. Meeting the COP 21 climate goals will require a clear path to a meaningful carbon price signal and changes beyond the energy sector across the economy. Most countries have commitments to increase their renewable energy generation to improve energy security and decrease $\mathrm{CO}_{2}$ emissions. To achieve this ambi- 
tious goal, a huge investment worldwide will be necessary. Also, as the scientists estimate, as much as threequarters of the world's coal, oil and gas reserves should remain in the ground if the world has to keep carbon emissions under levels set by the climate accord unless there is a technological breakthrough in capturing $\mathrm{CO}_{2}$ and keeping it out of the atmosphere.

The energy sector (electricity and heat) currently accounts for $41 \%$ of the global $\mathrm{CO}_{2}$ emissions and transport accounts for $23 \%$ and, to limit global warming to $2^{\circ} \mathrm{C}$ or less above preindustrial levels, energy-sector $\mathrm{CO}_{2}$ emissions will need to decline at an annual rate of $3.8 \%$ compared with a business as usual projected annual increase of $1.9 \%$, [47]. Governments and corporations are beginning to wrestle with the cost of climate change on their policies and many utilities are including a coming carbon tax into their long term power generation planning. Already, a shift in the global energy landscape, partly due a surge in drilling in oil and gas shale fields, has brought about a slump in fuel prices, calling into question the viability of future oil projects in far-flung places like the Arctic and deepwater oceans.

Fossil-based power generation is particularly hit by the above mentioned climate goal. IEA already calculates with 30 \$ton of $\mathrm{CO}_{2}$ emitted, [43], while the expected costs of avoiding emissions by the use of CCS are about 50 $\$$ /ton and by some other means even $100 \$$ /ton of $\mathrm{CO}_{2}$. Although the fossil fuel companies face the biggest climate change risks, the need for financial disclosure stretches to other industries as well. The recent estimates are that there are significant climate change risks for most industries. Many risks are quantifiable, but some companies claim that climate change is not among them. Yet, some agricultural companies reported that drought had reduced yields for corn and soybean harvest by as much as $31 \%$, and warned that the occurrence of severe adverse weather conditions, especially droughts, hail, floods or frost or diseases are unpredictable and may have a potentially devastating impact on the future agricultural production. A recent study on global financial assets put a price in terms of population. Even under a plan that would limit global warming to $2^{\circ} \mathrm{C}$, climate change could wipe out $\$ 1,700$ billion of global financial assets, which is $\$ 229.73$ for each man, woman and child on the Earth, [48].

\section{New Environmental Challenges}

\section{New Impacts of Renewable Energy Sources}

Solar energy is often hailed as the most environmentally benign source of electricity, and once a solar plant is in place, this is arguably true. But getting there has more environmental impacts. It starts with the silicon that forms the substrate of the most common types of solar PV cells. The most common method for producing polycrystalline silicon involves converting elemental silicon into gaseous form and then growing the silicon crystals through chemical vapor deposition. This process requires hydrochloric acid, and the resulting gas, trichlorosilane, is toxic, explosive, and corrosive. However, a US company has developed a completely different, much more environmentally friendly method of producing solar silicon that has the added benefit of costing half as much as traditional processes and using one-third the energy, [49].

Unlike solar PV cells, wind turbine manufacturing is relatively benign, or at least little different in impact from traditional turbine generators, since many of the same components are used. Wind turbines using permanent magnets require rare earth elements such as neodymium, the extraction of which can have serious environmental consequences because of the acids used in refining, and the frequent occurrence of uranium and thorium in the ores. Much more controversial has been the issue of bird mortality at operating wind farms. Though the scope of the impact has been heavily studied so far, the reported ranges are quite large, so that the estimates of bird mortality vary by an order of magnitude.

There is no tangible difference between geothermal and conventional fracking in terms of environmental impact. EGS can trigger earthquakes, most of which are very small and virtually unnoticeable, except when initiated on a seismic fault. Therefore, every project must be carefully monitored by seismometers in an attempt to assuage the concerns of environmental advocates. Nevertheless, critics continue to assert that acidic mixtures used for EGS may leak, contaminating surrounding soil and groundwater. As a result, local ecosystems may be severely compromised.

There are a number of environmental sustainability risks associated with increasing energy uses of biomass from forestry and agriculture. Growing demand for bio-energy has raised serious concerns about negative long term effects of removing forest residues for soil fertility, soil organic carbon, water quality and habitat. Increased harvesting and removal of forest residues and stumps for bio-energy are expected to have a greater impact on soil, water and habitat than conventional forest practices, [50]. The production of dedicated energy crops can also lead to negative developments like, for instance, increased emissions of GHGs or biodiversity losses through fertilizer use, or conversion of forest and carbon rich land into arable land. 


\section{New Impacts of Fossil Fired Power Plants}

Besides sulphur dioxide $\left(\mathrm{SO}_{2}\right)$, nitrogen oxides $\left(\mathrm{NO}_{\mathrm{x}}\right)$ and particles, there is a number of polluting agents coming out of chimney of power plants that are not yet the subject of environmental limits. It is expected that the potential new findings of their negative impact on human health could result in new limits of their emissions established by law. Figure 15 shows the share of some of these polluting agents coming from power plants in the total

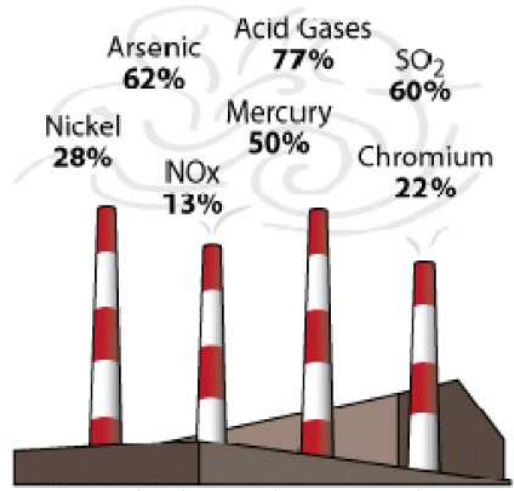

Figure 15: Share of emissions from power plants in total pollution in USA extreme variability, and of information on the risks presented from nickel emissions, still pose a significant obstacle. Nevertheless, it is reasonable to expect adequate standards to be enforced soon in the US, Europe, and elsewhere to limit nickel emissions.

\section{CONCLUSION}

The past years have seen unprecedented change in the consumption of energy resources with an unexpectedly high growth in the renewables market and growth of unconventional resources (oil shales, waste). More diversified energy mix achieved required considerable improvements in power technology for all the resources resulted in a decrease in energy prices. This energy transition requires a global response and an intensive pressure on the three dimensions of the so called 'energy trilemma' as individual countries aspire to improve energy security, expand energy equity and reduce carbon emissions.

The major challenge is to attract/arrange investment for energy infrastructure projects. Over the past decades, it has become clear that transforming centrally controlled energy systems into liberalized markets can create the right conditions to direct investment and facilitate competition. Therefore, energy must be priced appropriately to cover the full cost of supply, yet access to it should not be limited. Adjustments of pricing may be necessary to ensure that all consumers can afford to realize the benefits of energy. In the commercial sectors, energy pricing directly influences the competitiveness of goods and services, both locally and internationally.

The future electricity generation system is expected to be composed of a combination of central power plants, fueled with gas (natural gas in transition to biogas), biomass, nuclear power and large hydropower plants, as well as of numerous small decentralized plants based on renewable energy like wind, solar and biomass. The intermittency, which characterizes solar and wind power, is one of the central challenges in designing the new electricity system. However, although they cause challenges with regards to balancing electricity supply and demand in the current energy system, wind and solar power will be necessary for developing a sustainable energy system in the future. Energy storage needs to be a field of its own right, not just an add-on to renewable. It is further important to work on the market-terms and provide incentives for building storage energy systems.

Whichever scenario the future European energy system will follow, it will consist of a mixture of intermittent power and dispatchable power. Fossil fuels and nuclear power will dominate the European electricity system for the next 20-30 years at least. Even with the renewable proportion expanding massively, a large part of the power generation in Europe will be based on fossil fuels in the first half of this century. Gas is likely to play an important role in all possible scenarios of the future, especially if the EU Emissions Trading Scheme (ETS) would be established to work correctly (above $30 € /$ ton of $\mathrm{CO}_{2}$ ). 
The electricity system is changing, on both the generation and user sides. The role of decentralized energy is growing faster than that of conventional, central generation. Both generator and customer behavior is changing and these changes are inevitably altering the way how utilities operate, with electricity storage coming to the fore. The growth of the various distributed energy resources will force a major shift in utility business models. By far the most prevalent of these distributed resources will be new solar PV generation. Scaling-up renewable energy and storage with smart markets is challenging. The progress made with new renewable generation adding 'smart' electricity reforms and energy storage have the potential to further accelerate the energy transition.

There are new challenges in terms of ensuring the sustainability and reliability of energy supplies. Digitization is providing new insights into power plant operations and uncovering hidden opportunities to boost performance and availability. For some time, people are talking about the 'energy cloud', where distributed energy resources, making use of intelligent devices, storage and a smart grid, connect all manner of distributed loads and resources to meet customers' energy service needs. This results in higher availability and improved predictability of asset performance for power plant owners/operators. At the same time, however, it becomes a target for cyber attacks and therefore an increasing resilience to cyber risk is critical to current and future energy security.

\section{REFERENCES}

[1] , World Energy Resources. London: World Energy Council. 2016. pp. 1-1028.

[2] , World Energy Perspectives: Renewable Integration. London: World Energy Council. 2016. pp. 1-140.

[3] , World Energy Scenarios: The Grand Transition. London: World Energy Council. 2016. pp. 1-138.

[4] N. Slater-Thompson and S. Johnson, The World's Nine Largest Operating Power Plants are Hydroelectric Facilities. PennEnergy. 2016. October 18.

[5] M. Ćalović and et al., "Including Pumped Storage Hydro in Long-Term Generation Planning." Hydro Review Worldwide, vol. 23, no. 2, 2015 pp. 28-32.

[6] T. Bayar, "Wind to supply $20 \%$ of global power needs by 2030." World News, 2014 October 21.

[7] J.H. Baker, "Big Carbon Equals Big Solar." Transmission \& Distribution World, 2016 July 13.

[8] , Global Wind Energy Outlook. Brussels: Global Wind Energy Council. 2016. p. 44.

[9] Cardwell and D. Offshore, "Wind Farms See Promise in Platforms That Float." New York Times, 2016 September 29.

[10] , Statoil and Icelandic partners drill the world's hottest geothermal well. PennEnergy. 2016. September.

[11] L. Alton, "The Long-Term Effects of Harnessing Geothermal Energy." Renewable Energy World, 2016 October 19.

[12] M. Mesarović, "Sustainable Energy from Biomass." Thermal Science, vol. 5, no. 2, 2001, pp. 5-32.

[13] M. Krug, G. Rabczuk and A. Cenian, "Addressing Sustainability Risks of Bioenergy: Policy Strategies and Corporate Initiatives." Energy and Power Engineering, vol. 07, no. 05, 2015, pp. 217-241. doi: 10.4236/epe.2015.75022

[14] T. Stringfellow, "An Independent Engineering Evaluation of Waste-to-Energy Technologies." Renewable Energy World, 2014 January 13.

[15] B. Messenger, "A winning formula for waste to energy power plants." Power Engineering International, vol. 23, no. 6, 2016

[16] , New Power Generation: Coal Still the Dominant Fuel. Global Power. 2016. June 14.

[17] R. Ray, "Are Hybrid Systems the Next Big Trend in Power Generation?." Power Engineering International, vol. 23, no. 6, 2016

[18] , Power Generation. Germany: European Nuclear Society. 2014. Available from: https://www.euronuclear.org/info/encyclo pedia/p/pow-gen-ger.htm

[19] A. Cahen, "Climate Change and Energy: We Need a Bigger Boat." Power, vol. 160, no. 8, 2016

[20] M. Rosenbeg, Global Nuclear Surge. Washington: US Energy Information Agency. 2016.

[21] M. Scott, China expected to account for more than half of world growth in nuclear power through 2040. Washington: US Energy Information Agency. 2016. September 28.

[22] M. Ćalović and et al., "Market Challenges for Pumped Storage Hydropower Plants." International Journal of Computational Engineering Research, vol. 06, no. 03, 2016, pp. 2250-3005.

[23] M. Mesarović, "Energy Storage Technologies and Renewable Energy Sources." Termotehnika, vol. 34, no. 1, 2008, pp. 31-44. 
[24] S.A. Abdelrazek and J.H. Enslin, "Integrating Solar and Storage with the Grid." Transmission \& Distribution World, vol. 68, no. 8, 2016, pp. 38-43.

[25] , Global Transport Scenarios. London: World Energy Council. 2011. p. 76.

[26] G. Reitenbach, "The Progress of Power Technology." Power, vol. 160, no. 8 August, 2016

[27] M. Mesarovic, "Scientific uncertainties feed scepticism on climate change." Thermal Science, vol. 19, no. 2, 2015, pp. 259-278. doi: 10.2298/tsci150628194m

[28] S. Quoilin, M.V.D. Broek, S. Declaye, P. Dewallef and V. Lemort, "Techno-economic survey of Organic Rankine Cycle (ORC) systems." Renewable and Sustainable Energy Reviews, no. 22, 2013, pp. 168-186. doi: 10.1016/j.rser.2013.01.028

[29] , The Green Machine. Reno, Nevada, US: Electra Term. 2015.

[30] P. Ferguson, "More Communities Choose Their Own Energy Future." Power, vol. 160, no. 8, 2016

[31] , Community Micro-Grid Initiative - Innovation for a Clean Energy Future. Available from: www.cleancoalition.org/our-work/community-microgrids

[32] D. Hoeft, "Where Virtual Meets Reality." Power Engineering International, 2016 September.

[33] D. Williams, "Merits of the 'Energy Cloud' Explained in Milan." Power Engineering International, 2016 June.

[34] M. Rosenberg, "The New Utility Platform: Electric Service Delivered Like Uber and Airbnb." The Energy Times, 2016 October 10

[35] , World Energy Perspectives 2016: The road to Resilience: Managing CyberRisks. London: World Energy Council. 2016

[36] T. Bayar, "US funds fuel cell-driven on-site power." Decentralized Energy, vol. 11, no. 03, 2014

[37] , "Europe's first megawatt industrial fuel cell power plant officially in operation." PennEnergy, 2016 September 19.

[38] W. Krätzig, "Solar Updraft Power Technology: Fighting Global Warming and Rising Energy Costs." Journal of Technology Innovations in Renewable Energy, vol. 4, no. 2, 2015, pp. 52-64. doi: 10.6000/19296002.2015.04.02.2

[39] , World Energy Perspectives 2016: The road to Resilience - Managing the Risks of the Energy-Water-Food Nexus. London: World Energy Council. 2016.

[40] G. Reitenbach, "Will Tomorrow's Power Plants Have Enough Water?." Power, vol. 160, no. 9, 2016

[41] B. Carney, "New Technology Will Recover Heat \&Water from Flue Gas." Power Engineering, 2016 August 23.

[42] T. Bayar, "Global power investment down 8\% in 2015." Power Engineering International, 2016

[43] , International Energy Agency, Projected Costs of Generating Electricity. Paris. 2015.

[44] , New Power Generation: Coal Still the Dominant Fuel, Global Power, June 14, 2016

[45] M. Mesarović, "Black" or "Green" Approach to a Regional Long - Term Energy Development Planning", in WEC Central and Eastern Europe Energy Forum, FOREN, Bucharest. June. 2014.

[46] , Rethinking Energy. Masdar, UAE: International Renewable Energy Agency. 2015

[47] , World Energy Perspectives: The Road to Resilience-Financing Resilient Energy Infrastructure. London: World Energy Council. 2016. p. 55.

[48] M. Rosenberg, "The Cost of Climate Change-Dealing with Two Degrees of Heating." PennEnergy, 2016 September 27.

[49] , "Largest Solar Power Farm in the World Set for Nevada." Power Engineering, 2016 October 13.

[50] M. Krug, et al., Addressing Sustainability Risks of Bioenergy - Policy Strategies and Corporate Initiatives, Energy and Power Engineering, 2015, 7, pp. 217-241

[51] , Resource Adequacy Implications of Forthcoming EPA Air Quality Regulations. Washington: US Environmental Protection Agency. 2011

[52] T. Bayar, "A New Environmental Challenge: How to cut mercury emissions in coal-fired power plants." Power Engineering International, 2016, pp. 3-6.

Paper submitted: $\quad$ April 10, 2016

Paper revised: July 30, 2016

Paper accepted: $\quad$ August 27, 2016
Copyrights ${ }^{\odot} 2017$ Society of Thermal Engineers of Serbia Published by the VINCA Institute of Nuclear Sciences, Belgrade, Serbia This is an open access article distributed under the CC BY-NC-ND 4.0 terms and conditions 